Contents lists available at Journal IICET

JPPI (Jurnal Penelitian Pendidikan Indonesia)

ISSN: 2502-8103 (Print) ISSN: 2477-8524 (Electronic)

\title{
Analysis of vocational interests and student's perception of work-based on society 5.0 towards learning outcomes
}

\author{
Muhammad Anwar") \\ Universitas Negeri Padang, Indonesia
}

\begin{tabular}{l} 
Article Info \\
\hline Article history: \\
Received Feb $11^{\text {th }}, 2021$ \\
Revised Mar $17^{\text {th }}, 2021$ \\
Accepted Apr $30^{\text {th }}, 2021$ \\
\hline
\end{tabular}

\section{Keyword:}

Vocational interest

Perception of the world of work

Society 5.0

Learning outcomes

Engineering education

\begin{abstract}
The challenge of education in Indonesia with the entry of the era of society 5.0 requires efforts to improve student learning outcomes, especially engineering education students. This paper focuses on looking at the influence of vocational interest on learning outcomes, perceptions of the world of work based on society 5.0 on learning outcomes, and vocational interests and perceptions of the world of work together on learning outcomes. The results of the study found that (1) there was a significant influence between vocational interest on student learning outcomes by $10.3 \%$, (2) there was a significant influence between perceptions of the world of work based on society 5.0 on student learning outcomes by $11.3 \%$ and ( 3 ) there is a joint influence of vocational interest and perceptions of the world of work based on society 5.0 on student learning outcomes by $16 \%$. Thus, it can be concluded that vocational interest and perceptions about the world of work based on society 5.0 are two factors that contribute to student learning outcomes. This means that the higher the vocational interest and perception of the world of work based on society 5.0 , the student learning outcomes will tend to be higher.
\end{abstract}

(C) 2021 The Authors. Published by IICET.

This is an open access article under the CC BY-NC-SA license

(https://creativecommons.org/licenses/by-nc-sa/4.0)

\section{Corresponding Author:}

Muhammad Anwar

Universitas Negeri Padang

Email:muh_anwar@ft.unp.ac.id

\section{Introduction}

The development of the industrial world is currently undergoing very significant changes. In the industrial revolution 4.0, it has experienced a very strong evolution in influencing aspects of one's life through the combination of technology (Coş kun, Kayıkc1, \& Gençay, 2019), and is now surprised by the emergence of society 5.0. Described the present circumstances of society, suggested solutions for the achievement of a responsible human-centered society (Higashihara, 2018; Nakanishi, 2019). The rapid development of technology is oriented to solving social problems and preventing new problems from using technology. With advances in technology, human work is helped but humans remain the center of control. In a society in the era of society 5.0 (Salgues, 2018), students must be able to understand where their vocational interests and job opportunities are headed. Not only skilled in carrying out their duties but also must be able to create new jobs. The development process without skilled personnel will cause the development to become less efficient and unproductive and uncompetitive. The world of education is very closely related to the industrial world because the world of education must prepare education that refers to the development of the industrial world.

Vocational education is education that prepares students to become productive human beings and can immediately work in their fields after going through education (Tasrif, 2019). Vocational education is prepared 
for students to enter the world of work and be able to live independently (Ganefri et al., 2017; Ganefri et al., 2018), by itself can help the government reduce the unemployment rate and increase state income. One of this independence is through the entrepreneurial competence of engineering education graduates (Hidayat, 2015; Hidayat, 2017a, 2017b; Hidayat, \& Yuliana, 2018; Hidayat et al., 2018a, 2018b). Vocational interests, people who have realistic ideas, are curious about something, find something new, are able to get along with the community, are passionate, and have strong opinions (Holland, 1997). In pursuing vocational education students must have a vocational interest. Vocational interest is a preference for practices in the fields of carpentry, business (Hidayat et al., 2019a, 2019b, 2019c; Hidayat et al., 2020), industry, agriculture, transportation, and others. With the vocational interest in each student, they will be serious in responding to any knowledge. Interest will be shown by trying to get complete information, adapting to existing conditions, and trying to pay attention to every piece of information. This means that a student who has a vocational interest is expected to always look for complete information about vocational education, adapt to his needs and they will try to improve his lack of vocational skills.

The world of work is the final target after students complete their studies. Students must also understand the need for the world of work through their perception of the world of work in choosing a major (Polmear et al., 2019; Sánchez et al., 2019). Perception of the world of work is a view that is how a person perceives or interprets something, where a person's perception of the world of work is determined by its relevance to his needs. The perception of the world of work will also help students in making decisions about their future. With an understanding of the world of work, students will continue to explore the capabilities that exist within them to be able to compete in the world of work later (Anwar, 2019).

Based on the author's interviews with students, their perception of the world of work is still low. This is marked in the selection of majors, many of them in determining the majors more follow trends that are developing or are currently popular. Have not thought about where the final destination will be after graduating from an engineering education (Crawley et al., 2007; Felder et al., 2000; Holmegaard, Madsen, \& Ulriksen, 2016). In addition, students also do not understand what is needed by the world of work today. Learning outcomes are achievements that are achieved after participating in the learning process (Andrianis, Anwar, \& Zulwisli, 2018). Through these learning outcomes, we will be able to see how students' achievements during education (Inayat et al., 2013; Duque, 2014). Factors that affect learning outcomes can be classified into two factors, namely: internal factors (interest, intelligence, motivation, physical, talent, attitude, learning method, readiness, self-concept, cognitive abilities, and others) and external (family, school, community). and the world of work). In this case, vocational interest (Robertson et al., 2010; Glosenberg et al., 2019), and student's perceptions of the world of work will be able to influence student learning outcomes (Stoll et al., 2017).

\section{Method}

This study uses a descriptive correlation research method (Koh, \& Owen, 2000; Sneck et al., 2016). The analysis technique used is simple regression analysis and multiple regression which aims to test how much influence two independent variables have on one dependent variable. The instrument used is a Likert scale model. There are 3 variables in this study, namely: vocational interest (X1), perception of the world of work based on society $5.0(\mathrm{X} 2)$ as the independent variable, and learning outcomes $(\mathrm{Y})$ as the dependent variable.

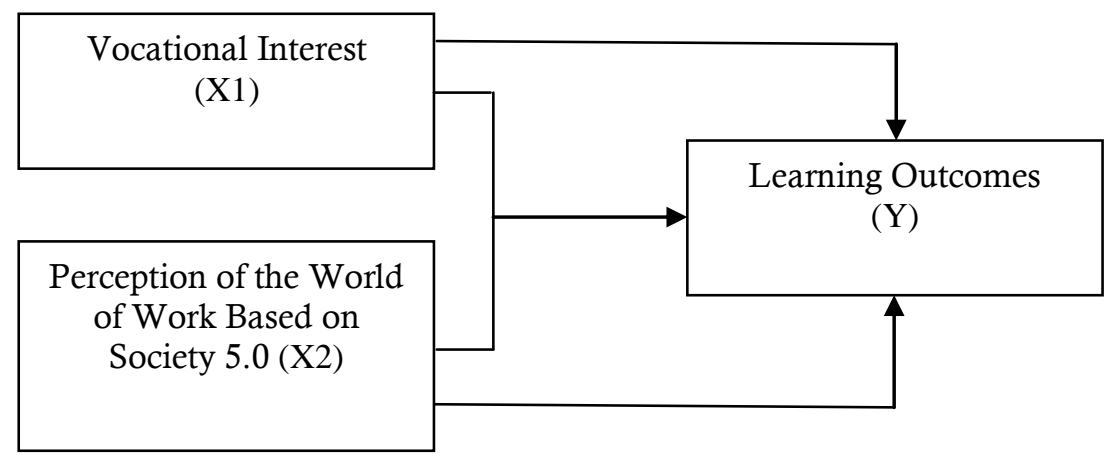

Figure 1. Conceptual Framework

The population in this study were students of the Informatics Engineering Education Study Program, Faculty of Engineering, Padang State University who had undergone lectures for 4 semesters as many as 134 
students. Sampling in this study using simple random sampling technique or random technique because the population used as a sample is all homogeneous or uniform. The sample size is based on a limited population formula, as shown in Figure 1 (Riduwan, 2009). From a population of 134 students, the required sample is 57 students.

The instruments used to collect data on the three variables are questionnaires and student learning outcomes. The questionnaire was compiled using a Likert scale with 5 alternative answers in the form of an attitude scale and frequency adjusted for the purpose of the question or statement, namely the Attitude Scale: strongly disagree (SD), disagree (DA), disagree (SD), agree (A) and strongly agree (SA) Frequency Scale: never $(\mathrm{N})$, rarely $(\mathrm{RR})$, sometimes $(\mathrm{ST})$, often $(\mathrm{O})$, always $(\mathrm{A})$. Data collection was carried out by distributing a test questionnaire to 30 students with 44 questions, then the validity and reliability tests were carried out, so there were 40 questions declared valid. Then the valid questionnaire was distributed to 57 samples. Data analysis with descriptive statistics of simple regression and multiple regression using SPSS version 16.0 program.

\section{The research hypothesis consists of 3 main problems:}

H1. There is a significant influence between Vocational Interests on Student Learning Outcomes.

H2. There is a significant influence between Perceptions of Society-Based Work World 5.0 on Student Learning Outcomes.

H3. There is a significant influence between Vocational Interest and Perceptions of the World of Work Based on Society 5.0 simultaneously on Student Learning Outcomes.

\section{Results and Discussions}

Prior to data analysis, normality, linearity and multicollinearity tests were carried out. The results of the normality test of the data obtained are Normality test using the Liliefors Kolmogorov-Smirnov test method with a significant level of $=5 \%$, Sig on the three variables the value is $0.200>$ (normally distributed data). Next, Linearity X1 $-\mathrm{Y}=0.016$ and $\mathrm{X} 2-\mathrm{Y}=0.008$, the two variables are linearly related because $<5 \%$. So it can be concluded that between the variables of vocational interest and perceptions of the world of work based on society 5.0 on learning outcomes there is a linear relationship. Then, the results of the Multicollinearity test obtained The VIF value of the two variables is $1,139<10$, meaning that there is no multicollinearity between the two variables, so there is no problem between the variables.

\section{Hypothesis Test}

Table 1. Model Summary of the Influence s of All Independent Variables on Dependent Variables

\begin{tabular}{ccccc}
\hline & \multicolumn{3}{c}{ Model Summary } \\
\hline Model & $\mathrm{R}$ & R Square & Adjusted R Square & Std. Error of the Estimate \\
\hline 1 & $.320^{\mathrm{a}}$ & .103 & .086 & .28776 \\
2 & $.336^{\mathrm{a}}$ & .113 & .097 & .28613 \\
3 & $.400^{\mathrm{a}}$ & .160 & .128 & .28103 \\
\hline
\end{tabular}

In table 2 the summary of the regression analysis between X1-Y obtained a significant influence with the regression coefficient $r=0.320$ and the regression between $\mathrm{X} 2$ - Y obtained a significant influence with the regression coefficient $r=0.336$. From Table 5 Model Summary, it shows that vocational interest has an influence on learning outcomes by $10.3 \%(\mathrm{R} 2=0.103)$ and perceptions of the world of work based on society 5.0 by $11.3 \%(\mathrm{R} 2=0.113)$. The summary of the regression analysis between $\mathrm{X} 1, \mathrm{X} 2$ - Y obtained a significant influence with the regression coefficient $r=0.400$. Table 6 shows that vocational interest and perceptions about the world of work together have an influence on learning outcomes by $16 \%(\mathrm{R} 2=0.160)$.

Table 2. Influence of X1, X2 on $\mathrm{Y}$

\begin{tabular}{|c|c|c|c|c|c|c|}
\hline \multicolumn{7}{|c|}{ ANOVA $^{b}$} \\
\hline & Model & $\begin{array}{l}\text { Sum of } \\
\text { Squares }\end{array}$ & $\mathrm{df}$ & Mean Square & $\mathrm{F}$ & Sig. \\
\hline 1 & Regression & .520 & 1 & .520 & 6.284 & $.015^{\mathrm{a}}$ \\
\hline & Residual & 4.554 & 55 & .083 & & \\
\hline & Total & 5.075 & 56 & & & \\
\hline
\end{tabular}

a. Predictors: (Constant), Vocational_Interests_X1

b. Dependent Variable: Student_Achievements_Y 


\begin{tabular}{|c|c|c|c|c|c|c|}
\hline \multicolumn{7}{|c|}{ ANOVA $^{\mathrm{b}}$} \\
\hline & Model & $\begin{array}{l}\text { Sum of } \\
\text { Squares }\end{array}$ & $\mathrm{df}$ & Mean Square & $\mathrm{F}$ & Sig. \\
\hline 1 & Regression & .572 & 1 & .572 & 6.988 & $.011^{\mathrm{a}}$ \\
\hline & Residual & 4.503 & 55 & .082 & & \\
\hline & Total & 5.075 & 56 & & & \\
\hline
\end{tabular}

a. Predictors: (Constant),

Students_Perceptions_About_Of_The_World_Of_Work_Society_5.0_X2

b. Dependent Variable: Student_Achievements_Y

Table 2 ANOVA, the value of Sig on the variable X1 $=0.015$ and Sig X2 $=0.011$. Both variables Sig value $<0.05$, it can be concluded that the variables $\mathrm{X} 1$ and $\mathrm{X} 2$ affect $\mathrm{Y}$

Table 3. Influence of $\mathrm{X} 1, \mathrm{X} 2$ together on $\mathrm{Y}$

\begin{tabular}{llrrrrr}
\hline \multicolumn{1}{c}{ Model } & Sum of Squares & df & $\begin{array}{c}\text { Mean } \\
\text { Square }\end{array}$ & F & Sig. & \\
\hline 1 & & & & & \\
\hline \multirow{2}{*}{1} & Regression & .810 & 2 & .405 & 5.128 & \\
\cline { 2 - 7 } & Residual & 4.265 & 54 & .079 & & \\
\cline { 2 - 6 } & Total & 5.075 & 56 & & & \\
\hline
\end{tabular}

a. Predictors: (Constant),

Students_Perceptions_About_Of_The_World_Of_Work_Society_5.0_X2,

Vocational_Interests_X1

b. Dependent Variable: Student_Achievements_Y

Table 3 ANOVA, the value of Sig $=0.009$, it can be concluded that the variables X1 and X2 together have an influence on $\mathrm{Y}$

The Influence of Vocational Interests on Learning Outcomes

The results of the regression test showed that vocational interest contributed $10.3 \%$ to learning outcomes. Significance also shows that vocational interest has an influence on learning outcomes. Various conditions that describe the high interest in student learning include the attention and participation of engineering education students in learning activities (Lee, Chao, \& Chen, 2011). Interest in doing vocational assignments, adding vocational insight, fun in vocational learning, and mastering the material contribute to learning outcomes (Minnaert et al., 2011; Nurahman et al., 2018). Interest is said to be a persistent tendency to pay attention and remember some activities. When someone has an interest in something, he will show a high sense of interest by paying attention continuously with feelings of pleasure (Krapp, 1999; Su, 2020). The findings of this study indicate that one of the student learning outcomes is related to the vocational interest of technical education students (McDowall, Jackling, \& Natoli, 2015; Jüttler et al., 2021).

\section{The Influence of Perceptions About Society-Based Work World 5.0 on Learning Outcomes}

The results of the regression test show that the perception of the world of work based on society 5.0 contributes $11.3 \%$ to learning outcomes. The significance also shows that the perception of the world of work based on society 5.0 has an influence on learning outcomes. Engineering education students' perceptions of the world of work based on Society 5.0 can be interpreted as student responses based on stimuli or stimuli to several work environments related to Society 5.0 which can change their life circumstances for the better by doing a number of activities (Ali, 2021). Perceptions of job opportunities, job availability, welfare, and job security are predicted to improve learning outcomes (O'Shea, Lysaght, \& Tanner, 2012). The findings of this study indicate that student learning outcomes, one of which is related to the perception of the world of work based on society 5.0 students, which is supported by several expert opinions including (Atkins, \& Flint, 2015) stating that Occupational Preference is not just choosing the best group of jobs according to someone's opinion. only, but also seeing the reality of the work, for example, can provide high wages and can provide a future/prosperity for a better future (Korkusuz, Durak, \& Ari, 2020).

The influence of vocational interests and perceptions of the world of work based on society 5.0 together on learning outcomes

The results of the multiple regression test show that vocational interest and perceptions of the world of work based on society 5.0 together contribute $16 \%$ to learning outcomes. Significance also shows that vocational interest and perceptions of the world of work based on society 5.0 have an influence on learning outcomes. Thus, student learning outcomes have an influence on the variables of vocational interest and perceptions of the world of work based on society 5.0 with student learning outcomes. 
There are two things that can affect student learning outcomes in engineering education, namely internal factors, and external factors. One of the factors from within students is psychological factors. Psychological factors that influence learning outcomes in engineering education are of interest. According to Sulfemi (2019), interest is a persistent tendency to pay attention and remember some activities. Activities that are of interest to students are considered continuously accompanied by a sense of pleasure, and a sense of satisfaction is obtained. Furthermore, that interest is a feeling of liking and interest in a thing or activity, without anyone telling. According to Kartika, Husni, \& Millah, (2019), argues that a person's interest in the learning process can be seen from the tendency to give greater attention to the learning process. It is further explained that if someone has a great interest in learning, the value of learning outcomes tends to change for the better, not least in the vocational interest of technical education students (Volodina, \& Nagy, 2016; Kumaidi, Farida, \& Haq, 2017; Kokou et al. al., 2018).

Students' vocational interest in learning in engineering education can be observed through curiosity, perseverance, pleasure, and attention of students as well as student enthusiasm in learning in engineering education (Annuar, \& Prima Zola, 2019; Glosenberg et al., 2019). One of the psychological factors that affect student learning outcomes in engineering education and is quite important to consider is perception. As Repelita (2018) argues that perception is an important factor in achieving student learning outcomes because perception can be a strength and a driving force for students to learn, as well as foster a sense of love and pleasure to learn. According to Wahyuni (2018), perception is an impression obtained by an individual through the five senses which are then analyzed, interpreted, and then evaluated, so that the individual gains meaning, including the perception of engineering education students towards the world of work based on society 5.0 (Gladden, 2019). A good and correct perception of the world of work based on society 5.0 can provide encouragement in the learning process so that it has an impact on the learning outcomes of engineering education students (Lakin et al., 2020). Technical education is education that provides competencies in certain areas of expertise that can later be useful and beneficial in society (Tasrif, 2019; Tasrif et al., 2021). Apart from the competencies possessed by engineering education graduates, they are also able to create jobs with their expertise (Trenor et al., 2008; Anwar, 2021), and entrepreneurship (Yulastri, \& Hidayat, 2017; Yulastri et al., 2018; Yulastri et al., 2019). The high vocational interest possessed by engineering education students and good and correct student perceptions of the world of work based on society 5.0 provide great advantages and benefits to the learning outcomes of engineering education students (Aryanti, Anwar, \& Zulwisli, 2017; Tasrif et al., 2020).

\section{Conclusions}

Based on data analysis and data testing, this research can be concluded that: 1) There is a significant influence between Vocational Interests on Student Learning Outcomes of 10.3\%; 2) There is a significant influence between Perceptions about the World of Work Based on Society 5.0 on Student Learning Outcomes of $11.3 \%$. There is a significant influence between Vocational Interest and Perceptions of the World of Work Based on Society 5.0 simultaneously on Student Learning Outcomes by $16 \%$.

\section{References}

Ali, M. (2021). Vocational students' perception and readiness in facing globalization, industry revolution 4.0 and society 5.0. In Journal of Physics: Conference Series (Vol. 1833, No. 1, p. 012050). IOP Publishing.

Andrianis, R., Anwar, M., \& Zulwisli, Z. (2018). Pengaruh Model Pembelajaran Berbasis Projek Terhadap Hasil Belajar Pemrograman Web Dinamis Kelas Xi Rekayasa Perangkat Lunak Di Smk Negeri 2 Padang Panjang. VoteTEKNIKA: Jurnal Vocational Teknik Elektronika dan Informatika, 6(1).

Annuar, Z., \& Prima Zola, S. T. (2019). Pengaruh Pelaksanaan Pengalaman Lapangan Industri Terhadap Minat Memilih Profesi Guru Bagi Mahasiswa Pendidikan Teknik Bangunan. CIVED (Journal of Civil Engineering and Vocational Education), 6(3).

Anwar, M. (2019). Kontribusi Self Efficacy Dan Self Regulated Terhadap Kesiapan Kerja Siswa Kelas Xii Teknik Audio Vidio Smk N 1 Padang. Jurnal Kapita Selekta Geografi, 2(10), 1-15.

Anwar, M. (2021). Problem Solving Skills Analysis of Vocational Engineering Teacher Candidates in Term of Several Variables. Journal of Education Technology, 5(1). doi:http://dx.doi.org/10.23887/jet.v5i1.33624

Aryanti, L., Anwar, M., \& Zulwisli, Z. (2017). Pengaruh Penerapan Model Pembelajaran Inkuiri Terhadap Hasil Belajar Teknik Elektronika Dasar Siswa Kelas X SMKN 5 Padang. VoteTEKNIKA: Jurnal Vocational Teknik Elektronika dan Informatika, 5(2).

Atkins, L., \& Flint, K. J. (2015). Nothing changes: perceptions of vocational education in England. International Journal of Training Research, 13(1), 35-48. 
Coşkun, S., Kayıkc1, Y., \& Gençay, E. (2019). Adapting engineering education to industry 4.0 vision. Technologies, 7(1), 10.

Crawley, E., Malmqvist, J., Ostlund, S., Brodeur, D., \& Edstrom, K. (2007). Rethinking engineering education. The CDIO Approach, 302, 60-62.

Duque, L. C. (2014). A framework for analysing higher education performance: students' satisfaction, perceived learning outcomes, and dropout intentions. Total quality management \& business excellence, 25(12), $1-21$.

Felder, R. M., Woods, D. R., Stice, J. E., \& Rugarcia, A. (2000). The future of engineering education: Part 2. Teaching methods that work. Chemical engineering education, 34(1), 26-39.

Ganefri, Hidayat, H., Kusumaningrum, I., \& Mardin, A. (2017). Needs Analysis of Entrepreneurship Pedagogy of Technology and Vocational Education with Production Based Learning Approach in Higher Education. International Journal of Advanced Science, Engineering and Information Technology, 7, 1701-1707. http://dx.doi.org/10.18517/ijaseit.7.5.1510

Ganefri, G., Hidayat, H., Yulastri, A., Mardin, A., Sriwahyuni, D., \& Zoni, A. A. (2018). Perangkat Pembelajaran Pedagogi Entrepreneurship Dengan Pendekatan Pembelajaran Berbasis Produk di Pendidikan Vokasi. In Prosiding Seminar Nasional \& Internasional, 1(1).

Gladden, M. E. (2019). Who will be the members of society 5.0? Towards an anthropology of technologically posthumanized future societies. Social Sciences, 1-39.

Glosenberg, A., Tracey, T.J.G., Behrend, T.S., Bluestein, D.L., \& Foster, L.L. (2019). Person-vocational fit across the world of work: Evaluating the generalizability of the circular model of vocational interests and social cognitive career theory across 74 countries. Journal of Vocational Behavior, 112, 92-108.

Hidayat, H. (2015). Production based Learning: An Instructional Design Model in the context of vocational education and training (VET). Procedia-Social and Behavioral Sciences, 204, 206-211.

Hidayat, H. (2017a). How is the Application and Design of a Product-Based Entrepreneurship Learning Tools in Vocational Higher Education?. In International Conference on Technology and Vocational Teachers (ICTVT 2017) (pp. 223-228). Atlantis Press.

Hidayat, H. (2017b). Impact of learning with the production-based learning model in vocational school. International Journal of Research in Engineering and Social Sciences, 7(2), 1-6.

Hidayat, H., Herawati, S., Tamin, B. Y., \& Syahmaidi, E. (2018a). How is the practicality of technopreneurship Scientific learning model design in vocational higher education?. International Journal of Scientific Research and Management, 6(09).

Hidayat, H., Herawati, S., Syahmaidi, E., Hidayati, A., \& Ardi, Z. (2018b). Designing of technopreneurship scientific learning framework in vocational-based higher education in Indonesia. International Journal of Engineering and Technology (UAE), 7(4), 123-127.

Hidayat, H., \& Yuliana. (2018). The Influence of Entrepreneurship Education and Family Background on Students' Entrepreneurial Interest in Nutritious Traditional Food Start Ups in Indonesia. International Journal of Engineering and Technology(UAE). 7(4), 118-122. https://doi.org/10.14419/ijet.v7i4.9.20631

Hidayat, H., Tamin, B. Y., Herawati, S., Khairul, K., \& Syahmaidi, E. (2019a). The contribution of technopreneurship scientific learning and learning readiness towards the entrepreneurship learning outcomes in higher vocational education. Jurnal Pendidikan Vokasi, 9(1), 21-32.

Hidayat, H., Ardi, Z., Yuliana, \& Herawati, S. (2019b). Exploration of the need analysis for technopreneurship scientific learning models in higher vocational education. International Journal of Economics and Business Research, 18(3), 356-368.

Hidayat, H., Tamin, B.Y., Herawati, S., Hidayati, A., Muji, A.P. (2019c). Implementation of technopreneurship scientific learning for produce electronic product prototypes in engineering education. International Journal of Innovative Technology and Exploring Engineering, 8(11), 2842-2846. http://dx.doi.org/10.35940/ijitee.K2406.0981119

Hidayat, H., Tamin, B. Y., Herawati, S., Ardi, Z., \& Muji, A. P. (2020). The Contribution of Internal Locus of Control and Self-Concept to Career Maturity in Engineering Education. Int. J. Adv. Sci. Eng. Inf. Technol, 10(6), 2282-2289.

Higashihara, T. (2018). A Search for Unicorns and the Building of Society 5.0. World Economic Forum, Davos.

Holland, J. L. (1997). Making vocational choices: A theory of vocational personalities and work environments (3rd ed.). Odessa, Fla.: Psychological Assessment Resources.

Holmegaard, H. T., Madsen, L. M., \& Ulriksen, L. (2016). Where is the engineering I applied for? A longitudinal study of students' transition into higher education engineering, and their considerations of staying or leaving. European Journal of Engineering Education, 41(2), 154-171.

Inayat, I., ul Amin, R., Inayat, Z., \& Salim, S. S. (2013). Influence s of collaborative web based vocational education and training (VET) on learning outcomes. Computers \& education, 68, 153-166. 
Jüttler, A., Schumann, S., Neuenschwander, M. P., \& Hofmann, J. (2021). General or Vocational Education? The Role of Vocational Interests in Educational Decisions at the End of Compulsory School in Switzerland. Vocations and Learning, 14(1), 115-145.

Kartika, S., Husni, H., \& Millah, S. (2019). Pengaruh Kualitas Sarana Dan Prasarana Terhadap Minat Belajar Siswa Dalam Pembelajaran Pendidikan Agama Islam. Jurnal Penelitian Pendidikan Islam,[SL], 7(1), 113126.

Koh, E. T., \& Owen, W. L. (2000). Descriptive research and qualitative research. In Introduction to Nutrition and Health research, 219-248. Springer, Boston, MA.

Kokou, A, Atitsogbe., I, A, Moumoula., S, Rochat., J, P, Antonietti, \& J, Rossier. (2018). Vocational Interests and Career Indecision in Switzerland and Burkina Faso : Cross-Cultural Similarities and Differences. Journal of Vocational Behavior, 107, 126-140

Korkusuz, M. E., Durak, G., \& Ari, N. K. (2020). Metaphoric Perceptions Of Undergraduate And High School Students About The Concepts Of Industry 4.0 and Society 5.0. Necatibey Faculty of Education Electronic Journal of Science \& Mathematics Education, 14(2).

Krapp, A. (1999). Interest, motivation and learning: An educational-psychological perspective. European journal of psychology of education, 14(1), 23-40.

Kumaidi, K., Farida, R., \& Haq, A. H. B. (2017). Skala Minat Kejuruan: Strategi Mengenali Minat Vokasi Siswa. URECOL, 553-562.

Lakin, J. M., Wittig, A. H., Davis, E. W., \& Davis, V. A. (2020). Am I an engineer yet? Perceptions of engineering and identity among first year students. European Journal of Engineering Education, 45(2), 214231.

Lee, Y. J., Chao, C. H., \& Chen, C. Y. (2011). The influences of interest in learning and learning hours on learning outcomes of vocational college students in Taiwan: using a teacher's instructional attitude as the moderator. Global journal of engineering education, 13(3), 140-153.

McDowall, T., Jackling, B., \& Natoli, R. (2015). Relationships between vocational interests and learning approaches to advance the quality of student learning in accounting. Accounting Education, 24(6), 498-513.

Minnaert, A., Boekaerts, M., De Brabander, C., \& Opdenakker, M. C. (2011). Students' experiences of autonomy, competence, social relatedness and interest within a CSCL environment in vocational education: The case of commerce and business administration. Vocations and Learning, 4(3), 175.

Nakanishi, H. (2019.) Modern Society Has Reached Its Limits - "Society 5.0" Will Liberate us. World Economic Forum, Davos.

Nurahman, A., Widodo, W., Ishafit, I., \& Saulon, B. O. (2018). The development of worksheet based on guided discovery learning method helped by phet simulations interactive media in newton's laws of motion to improve learning outcomes and interest of vocational education 10 th grade students. Indonesian Review of Physics, 1(2), 37-41.

O'Shea, S., Lysaght, P., \& Tanner, K. (2012). Stepping into higher education from the vocational education sector in Australia: Student perceptions and experiences. Journal of Vocational Education \& Training, 64(3), 261-277.

Polmear, M., Bielefeldt, A. R., Knight, D., Canney, N., \& Swan, C. (2019). Analysis of macroethics teaching practices and perceptions in engineering: a cultural comparison. European Journal of Engineering Education, 44(6), 866-881.

Repelita, T. (2018). Pengaruh Persepsi Siswa Atas Kinerja Guru dan Motivasi Belajar terhadap Prestasi Menulis Bahasa Indonesia pada Siswa SMA Swasta Jakarta Timur. Pujangga, 2(1), 67-120.

Riduwan. (2009). Belajar Mudah Penelitian Untuk Guru dan Karyawan dan Peneliti Pemula. Bandung : Alfabeta.

Robertson, K. F., Smeets, S., Lubinski, D., \& Benbow, C. P. (2010). Beyond the threshold hypothesis: Even among the gifted and top math/science graduate students, cognitive abilities, vocational interests, and lifestyle preferences matter for career choice, performance, and persistence. Current Directions in Psychological Science, 19(6), 346-351.

Salgues, B. (2018). Society 5.0: industry of the future, technologies, methods and tools. John Wiley \& Sons.

Sánchez, A., Gonzalez-Gaya, C., Zulueta, P., \& Sampaio, Z. (2019). Introduction of building information modeling in industrial engineering education: Students' perception. Applied sciences, 9(16), 3287.

Sneck, S., Saarnio, R., Isola, A., \& Boigu, R. (2016). Medication competency of nurses according to theoretical and drug calculation online exams: A descriptive regressional study. Nurse education today, 36, 195-201.

Stoll, G., Rieger, S., Lüdtke, O., Nagengast, B., Trautwein, U., \& Roberts, B. W. (2017). Vocational interests assessed at the end of high school predict life outcomes assessed 10 years later over and above IQ and Big Five personality traits. Journal of personality and social psychology, 113(1), 167. 
$\mathrm{Su}, \mathrm{R}$. (2020). The three faces of interests: An integrative review of interest research in vocational, organizational, and educational psychology. Journal of Vocational Behavior, 116, 103240.

Sulfemi, W. B. (2019). Model pembelajaran kooperatif mind mapping berbantu audio visual dalam meningkatkan minat, motivasi dan hasil belajar IPS. Jurnal PIPSI (Jurnal Pendidikan IPS Indonesia), 4(1), 13-19.

Tasrif, E. (2019). Academic Supervision Mechanism by Vocational High School Supervisor. In 5th UPI International Conference on Technical and Vocational Education and Training (ICTVET 2018) (pp. 160-164). Atlantis Press.

Tasrif, E., Kurnia, H., Pahtoni, T. Y., Kurniadi, D., \& Hadi, A. (2020). Analysis of Development Needs of Foster Parents Communication Media in Supporting Improvement of Academic Achievement of Students with Weak Socio-Economic Background. In The 1st Progress in Science and Technology Research Symposium. Redwhite Press.

Tasrif, E., Saputra, H. K., Kurniadi, D., Hidayat, H., \& Mubai, A. (2021). Designing Website-Based Scholarship Management Application for Teaching of Analytical Hierarchy Process (AHP) in Decision Support Systems (DSS) Subjects. International Journal of Interactive Mobile Technologies, 16(9).

Trenor, J. M., Yu, S. L., Waight, C. L., Zerda, K. S., \& Sha, T. L. (2008). The relations of ethnicity to female engineering students' educational experiences and college and career plans in an ethnically diverse learning environment. Journal of engineering education, 97(4), 449-465.

Volodina, A., \& Nagy, G. (2016). Vocational choices in adolescence: The role of gender, school achievement, self-concepts, and vocational interests. Journal of Vocational Behavior, 95, 58-73.

Yulastri, A., \& Hidayat, H. (2017). Developing an Entrepreneurship Module by Using Product-Based Learning Approach in Vocational Education. International Journal of Environmental and Science Education, 12(5), 1097-1109.

Yulastri, A., Hidayat, H., Ganefri, G., Edya, F., \& Islami, S. (2018). Learning outcomes with the application of product based entrepreneurship module in vocational higher education. Jurnal Pendidikan Vokasi, 8(2), 120-131.

Yulastri, A., Hidayat, H., Ganefri, Ayu, R., \& Ardi, Z. (2019). An Empirical Study on The Influence s of Pedagogy Learning Tools Entrepreneurship With Product-Based Learning Approach, Learning Readiness, and Locus of Control: A Case From Engineering Education in Indonesia. International Journal of Scientific \& Technology Research, 8(9), 1722-1727.

Wahyuni, D. (2018). Persepsi siswa tentang keadaan psikologis sense of humor guru dengan motivasi belajar siswa kelas VII SMPN 3 Batusangkar. Alfuad: Jurnal Sosial Keagamaan, 1(1), 81-92. 